\section{A SHORT HISTORY OF SCIENTIFIC INSTRUCTION. ${ }^{1}$}

I.

THE two addresses by my colleagues Profs. Judd and Roberts-Austen have drawn attention to the general history of our College and the details of one part of our organisation. I propose to deal with another part, the consideration of which is of very great importance at the present time, for we are in one of those educational movements which spring up from time to time and mould the progress of civilisation. The question of a Teaching University in the largest city in the world, Secondary Education, and so-called Technical Education are now occupying men's ninds.

At the beginning it is imperative that I should call your attention to the fact that the stern necessities of the human race have been the origin of all branches of science and learning; that all so-called educational movements have been based upon the actual requirements of the time. There has never been an educational movement for learning's sake; but of course there have always been studies and students apart from any of those general movements to which I am calling attention; still we have to come down to the times of Louis Quatorze before the study of the useless, the même inutile, was recognised as a matter of national concern.

It is perhaps the more necessary to insist upon stern necessity as being the origin of learning, because it is so difficult for us now to put ourselves in the place of those early representatives of our race that had to face the problems of life among conditionings of which they were profoundly ignorant: when night meant death; when there was no certainty that the sun would rise on the morrow; when the growth of a plant from seed was unrecognised; when a yearly return of seasons might as well be a miracle as a proof of a settled order of phenomena ; when, finally, neither cause nor effect had been traced in the operations of nature.

It is doubtless in consequence of this difficulty that some of the early races have been credited by some authors with a special love of abstract science, of science for its own sake; so that this, and not stern necessity, was the motive of their inquiries. 'Thus we have been told that the Chaldreans differed from the other early races in having a predilection for astronomy, another determining factor being that the vast plains in that country provided them with a perfect horizon.

The first historic glimpses of the study of astronomy we find among the peoples occupying the Nile Valley and Chaldra, say 6000 B.C.

But this study had to do with the fixing of the length of the year, and the determination of those times in it in which the various agricultural operations had to be performed. These were related strictly to the rise of the Nile in one country and of the Euphrates in the other. All human activity was in fact tied up with the movements of the sun, moon and stars. These, then, became the gods of those early peoples, and the astronomers, the seers, wcre the first priests ; revered by the people because as interpreters of the celestial powers they were the custodians of the knowledge which was the most necessary for the purposes of life.

Eudemus of Rhodes, one of the principal pupils of Aristotle, in his History of Geometry, attributes the origin of geometry to the Egyptians, "who were obliged to invent it in order to restore the landmarks which had been destroyed by the inundation of the Nile," and observes "that it is by no means strange that the invention of the Sciences should have originated in practical needs." 2 The new geometry was brought from Eyypt to Greece by Thales three hundred years before Aristotle was born.

1 An address delivered at the Royal College of Science by Sir Nurman Lockyer, K.C.B., F.R.S., on October 6

2 "Greek Geometry from Thales to Euclid," p. 2. (Allman.) NO. I 511 , VOL. 58$]$
When to astronomy and geometry we add the elements of medicine and surgery, which it is known were familiar to the ancient Egyptians, it will be conceded that we are, in those early times, face to face with the cultivation of the most useful branches of science.

Now, although the evidence is increasing day by day that Greek science was Egyptian in its origin, there is no doubt that its cultivation in Greece was more extended, and that it was largely developed there. One of the most useful and prolific writers on philosophy and science who has ever lived. Aristotle, was born in the fourth century B.C. From him, it may be said, dates a general conception of science based on observation as differing from experiment. If you wish to get an idea of the science of those times, read his writings on Physics and on the Classification of Animals. All sought in Aristotle the basis of knowledge, but they only read his philosophy; Dante calls him "the Master of those who know."1

Why was Aristotle so careful to treat science as well as philosophy, with which his master, Plato, had dealt almost exclusively?

The answer to this question is of great interest to our present subject. The late Lord Playfair ${ }^{2}$ in a pregnant passage, suggests the reason, and the later history of Europe shows, I think, that he is right.

"We find that just as early nations became rich and prosperous, so did philosophy arise among them, and it declined with the decadence of material prosperity. In those splendid days of Greece, when Plato, Aristotle, and Zeno were the representatives of great schools of thought, which still exercise their influence on mankind, Greece was a great manufacturing and mercantile community; Corinth was the seat of the manufacture of hardware; Athens that of jewellery, shipbuilding and pottery. The rich men of Greece and all its free citizens were actively engaged in trade and commerce. The learned class were the sons of those citizens, and were in possession of their accumulated experience derived through industry and foreign relations. Thales was an oil merchant ; Aristotle inherited wealth from his father, who was a physician, but, spending it, is believed to have supported himself as a druggist till Philip appointed him tutor to Alexander. Plato's wealth was largely derived from commerce, and his master, Socrates, is said to have been a sculptor. Zeno, too, was a travelling merchant. Archimedes is perhaps an exception, for he is said to have been closely related to a prince ; but if so, he is the only princely discoverer of science on record."

In ancient Greece we see the flood of the first great intellectual tide. Alas : it never touched the shores of Western Europe, but it undoubtedly reached to Rome, and there must have been very much more observational science taught in the Roman studia than we generally imagine, otherwise how account for Pliny, the vast public works, their civilising influence carried over sea and land from beyond Bab-el-Mandeb to Scotland? In some directions their applications of science are as yet unsurpassed.

With the fall of the Roman Empire both science and philosophy disappeared for a whıle. The first wave had come and gone; its last feebler ripples seem to have been represented at this time by the gradual change of the Roman secular studia wherever they existed into clerical schools, the more important of which were in time attached to the chief cathedrals and monasteries; and it is not difficult to understand why the secular (or scientific) instruction was gradually replaced by one more fitted for the training of priests.

It is not to be wondered at that the ceaseless strife in the centre of Europe had driven what little learning there was to the Western and Southern extremities where

\footnotetext{
1 "Inferno," c. iv. 30 et seg.
2 "Subjects of Social Welfare," p. 205
} 
the turmoil was less-I refer to Britain and South Italywhile the exiled Nestorians carried Hellenic science and philosophy out of Europe altogether to Mesopotamia and Arabia.

The next wave, it was but a small one, had its origin in our own country. In the eighth century England was at its greatest height, relatively, in educational matters; chiefly owing to the labours of two men. Beda, generally called the Venerable Bede, the most eminent writer of his age, was born near Monkwearmouth in 673, and passed his life in the monastery there. $\mathrm{He}$ not only wrote the history of our island and nation, but treatises on the nature of things, astronomy, chronology, arithmetic, medicine, philosophy, grammar, rhetoric, poetry, music basing his work on that of Pliny. He died in 735, in which year his great follower was born in Yorkshire, I refer to Alcuin. He was educated at the Cathedral School at York under Archbishop Egbert, and having imbibed everything he could learn from the writings of Bede and others, was soon recognised as one of the greatest scholars of the time. On returning from Rome, whither he had been sent by Eaubald to receive the pallium, he met Karl the Great, King of the Franks and Lombards, who eventually induced him to take up his residence at his Court, to become his instructor in the sciences. Karl (or Charlemagne) then was the greatest figure in the world, and although as King of the Franks and Lombards, and subsequently Emperor of the Holy Roman Empire, his Court was generally at Aachen, he was constantly travelling throughout his dominions. He was induced, in consequence of Alcuin's influence, not only to have a school always about him on his journeys, but to establish, or foster, such schools wherever he went. Hence it has been affirmed that "France is indebted to Alcuin for all the polite learning it boasted of in that and the following ages." The Universities of Paris, Tours, Fulden, Soissons and others were not actually founded in his day, but the monastic and cathedral schools out of which they eventually sprung were strengthened, and indeed a considerable scheme of education for priests was established ; that is, an education free from all sciences, and in which philosophy alone was considered.

Karl the Great died in 814 , and after his death the eastward travelling wave, thus started by Bede and Alcuin, slightly but very gradually increased in height. 'Two centuries later, however, the conditions were changed. We find ourselves in presence of interference phenomena, for then there was a meeting with another wave travelling westwards, and this meeting was the origin of the European Universities. The wave now manifested travelling westerly, spread outward from Arab centres first and finally from Constantinople, when its vast stores of Greek lore were opened by the conquest of the city.

The first wavelet justified Eudemus' generalisation that "the invention of the Sciences originated in practical needs," and that knowledge for its own sake was not the determining factor. The year had been determined, stone circles erected almost everywhere, and fires signalled from them, giving notice of the longest and shortest days, so that agriculture was provided for, even away from churches and the Festivals of the Church. The original user of geometry was not required away from the valleys of the Nile, Tigris and Euphrates, and, therefore, it is now Medicine and Surgery that come to the front for the alleviation of human ills. In the eleventh century we find Salerno, soon to be famed throughout Europe as the great Medical School, forming itself into the first University. And Medicine did not exhaust all the science taught, for Adelard listened there to a lecture on "the nature of things," the cause of magnetic attraction being one of the "things" in question.

NO. I 5 I I, VOL. 58 ]
This teaching at Salerno preceded by many years the study of the law at Bologna and of theology at Paris.

The full flood came from the disturbance of the Arab wave-centre by the Crusades, about the beginning of the twelfth century. After the Pope had declared the "Holy War," William of Malmesbury tells us, "The most distant islands and savage countries were inspired with this ardent passion. The Welshman left his hunting, the Scotchman his fellowship with vermin, the Dane his drinking party, the Norwegian his raw fish." Report has it that in 1096 no less than six millions were in motion along many roads to Palestine. This, no doubt, is an exaggeration, but it reflects the excitement of the time, and prepares us for what happened when the Crusaders returned ; as Green puts it," "the western nations, including our own, 'were quickened with a new life and throbbing with a new energy.' . . . A new fervour of study sprang up in the West from its contact with the more cultured East. Travellers like Adelard, of Bath, brought back the first rudiments of physical and mathematical science from the schools of Cordova or Bagdad. ... The long mental inactivity of feudal Europe broke up like ice before a summer's sun. Wandering teachers, such as Lanfranc or Anselm, crossed sea and land to spread the new power of knowledge. The same spirit of restlessness, of inquiry, of impatience with the older traditions of mankind, either local or intellectual, that drove half Christendom to the tomb of its Lord, crowded the roads with thousands of young scholars hurrying to the chosen seats where teachers were gathered together."

Studium generale was the term first applied to a large educational centre where there was a guild of masters, and whither students flocked from all parts. At the beginning of the thirteenth century the three principal studia were Paris, Bologna and Salerno, where theology and arts, law and medicine, and medicine almost by itself, were taught respectively ; these eventually developed into the first universities. ${ }^{2}$

English scholars gathered in thousands at Paris round the chairs of William of Champeaux or Abelard, where they took their place as one of the "nations" of which the great Middle Age University of Paris was composed.

We have only to do with the Arts faculty of this University. We find that the subject-matter of the liberal education of the Middle Age there dealt with varied very little from that taught in the schools of ancient Rome.

The so-called "artiens," students of the Arts faculty, which was the glory of the University and the one most numerously attended, studied the seven arts of the trivium and quadrivium-that is, grammar, rhetoric, dialectic and arithmetic, geometry, music, astronomy. ${ }^{3}$

This at first looks well for scientific study, but the mathematics taught had much to do with magic; arithmetic dealt with epacts, golden numbers, and the like. There was no algebra, and no mechanics. Astronomy dealt with the system of the seven heavens.

Science, indeed, was the last thing to be considered in the theological and legal studia, and it would appear that it was kept alive more in the medical schools than in the Arts faculties. Aristotle's writings on physics, biology, and astronomy were not known till about 1230 , and then in the shape of Arab-Latin translations. Still it must not be forgotten that Dante learned some of his astronomy, at all events, at Paris.

Oxford was an offshoot of Paris, and therefore a theological studium, in all probability founded about 1167,4 and Cambridge came later.

Not till the Reformation (sixteenth century) do we see

1 "History of the English People," I. r98.

2 See "Historie de l'Université de Paris." Crévier, 179r, passin.

3 Enumerated in the following Middle Age Latin verse:

4. "Universities of Europe in the Middle Ages," Rashdall, vol. ii. p. 344 
any sign of a new educational wave, and then we find the two which have had the greatest influence upon the history of the world-one of them depending upon the Reform. ation itself, the other depending upon the birth of experimental inquiry.

Before the Reformation the Universities were priestly institutions, and derived their authority from the Popes.

The Universities were for the few; the education of the people, except in the various crafts, was unprovided for.

The idea of a general education in secular subjects at the expense of the State or of communities is coeval with the Reformation. In Germany, even before the time of Luther, it was undreamt of, or rather, perhaps, one should say, the question was decided in the negative. In his day, however, his zeal first made itself heard in favour of education, as many are now making themselves heard in favour of a better education, and in 1524 he addressed a letter to the Councils of all the towns in Germany, begging them to vote money not merely for roads, dikes, guns, and the like, but for schoolmasters, so that all children might be taught; and he states his opinion that if it be the duty of a State to compel the able-bodied to carry arms, it is a fortiori its duty to compel its subjects to send their children to school, and to provide schools for those who without such aid would remain uninstructed.

Here we have the germ of Germany's position at the present day, not only in scientific instruction but in everything which that instruction brings with it.

With the Reformation this idea spread to France. In I 560 we find the States General of Orleans suggesting to Francis II. a "levée d'une contribution sur les bénéfices ecclésiastiques pour raisonablement stipendier des pédagogues et gens lettrés, en toutes villes et villages, pour l'instruction de la pauvre jeunesse du plat pays, et soient tenus les pères et mères, à peine d'amende, à envoyer les dits enfants à l'école, et à ce faire soient contraints par les segnieurs et les juges ordinaires."

Two years after this suggestion, however, the religious wars broke out ; the material interests of the clerical party had predominated, the new spirit was crushed under the iron heel of priestcraft, and the French, in consequence, had to wait for three centuries and a revolution before they could get comparatively free.

In the Universities, or at all events alongside them, we find next the introduction, not so much yet of science, as we now know it, with its experimental side, as of the scientific spirit.

The history of the Collége de France, founcled in I $53 \mathrm{I}$ by Francis the First, is of extreme interest. In the fifteenth century, the studies were chiefly literary, and except in the case of a few minds they were confined merely to scholastic subtleties, taught (I have it on the authority of the Statistique de l'Enseignement Supérieur) in barbarous Latin. This was the result of the teaching of the faculties; but even then, outside the faculties, which were immutable, a small number of distinguished men still occupied themselves in a less rigid way in investigation; but still these studies were chiefly literary. Among those men may be mentioned Dands, Postel, Dole, Guillaume Budé, Lefevre d'Étaples, and others, who edited with notes and commentaries Greek and Latin authors whom the University scarcely knew by name. Hence the renaissance of the sixteenth century, which gave birth to the Collége de France, the function of which, at the commencement, was to teach those thlngs which were not in the ordinary curriculum of the faculties. It was called the Colle'ge des Deux Langues, the languages being Hebrew and Greek. It then became the College des Irois Langues, when the king, notwithstanding the opposition of the University, created in I534 a chair of Latin. There was another objection made by the University to the new creation : from the commencement the courses were free; and this feelıng was not decreased by the fact that around the celebrated masters of the Trois Langues a crowd of students was soon congregated.

The idea in the mind of Francis the First in creating this Royal College may be gathered from the following Edict; dated in I 545 : "François, \&c., savoir faisons à tous présents et à venir que Nous, considérant que le sçavoir des langues, qui est un des dons du Saint-Esprit, fait ouverture et donne le moyen de plus entière connaissance et plus parfaite intelligence de toutes bonnes, honnêtes, saintes et salutaires sciences. . . . Avons fait faire pleinement entendre à ceux qui, y voudraient vacquer, les trois langues principales, Hébraïque, Grecque, et Latıne, et les Lizires esquels les bonnes sciences sont le mieux et le plus profondément traitées. A laquelle fin, et en suivant le décret du concile de Vienne, nous avons piéça ordonné et establi en nôtre bonne ville de Paris, un bonne nombre de personnages de sçavoir excellent, qui lisent et enseignent publiquement et ordinairement les dites langucs et sciences, maintenant florissant autant ou plus qu'elles ne firent de bien longtemps.... auxquels nos lecteurs avons donné honnêtes gages et salaires, et iceux fait pourvoir de plusieurs beaux bénéfices pour les entretenir et donner occasion de mieux et plus continuellement entendre au fait de leur charge. ... \&c."

The Statistique, which I am following in this account, thus sums up the founder's intention :- - "Le Collége Royal avait pour mission de propager les nouvelles connaissances, les nouvelles découvertes. Il n'enseignait pas la science faite, il la faisait."

It was on account of this, more than on account of anything else, that it found its greatest enemy in the University. The founding of this new College, and the great excitement its success occasioned in Paris, were, there can be little doubt, among the factors which induced Gresham to found his College in London in 1574

These two institutions played a great part in their time. Gresham College, it is true, was subsequently strangled, but not before its influence had been such as to permit the Royal Society to rise phœnix-like from its ashes, for it is on record that the first step in the forming of this Society was taken after a lecture on astronomy by Sir Christopher Wren at the College. All connected with them felt in time the stupendous change of thought in the century which saw the birth of Bacon, Galileo, Gilbert, Hervey, Tycho IBrahe, Descartes and many others that might be named; and of these, it is well to remark, Gilbert, ${ }^{1}$ Hervey and Galileo were educated in medical schools abroad.

Bacon was not only the first to lay down regulce philosophandi, but he insisted upon the far-reaching results of research, not forgetting to point out that "lucifera experimenta, non fructifera quarenda," 2 as a caution to the investigator, though he had no doubt as to the revolution about to be brought about by the ultimate application of the results of physical inquiry.

As early as $1 ; 60$ the Academia Secretorum Natura was founded at Naples, to be followed by the Lincei in I 609 , the Royal Society in 1645 , the Cimento in 1657 , and the Paris Academy in 1666 .

From that time the world may be said to have belonged to science, now no longer based merely on observation but on experiment. But, alas ! how slowly has it percolated into our Universities.

The first organised endeavour to teach science in schools was naturally made in Germany (Prussia), where, in 1747 (nearly a century and a half ago), Realschulen were first started; they were taken over by the Government in 1832 , and completely reorganised in 1859 , this step being demanded by the growth of industry and the spread of the modern spirit. Eleven hours a week were given to natural science in these schools forty years ago.

1 "William Gilbert, of Colchester, on the Magnet." Mittelag, p. x.

NO. I 5 I I, VOL. 58 ] 


\section{Teaching the Teachers.}

Until the year 1762 the Jesuits had the education of France almost entirely in their hands, and when, therefore, their expulsion was decreed in that year, it was only a necessary step to create an institution to teach the future teachers of France. Here, then, we had the École Normale in theory; but it was a long time before this theory was carried into practice, and very probably it would never have been had not Rolland d'Erceville made it his duty, for more than twenty years, by numerous publications, amongst which is especially to be mentioned his "Plan d'Education," printed in 1783 , to point out, not merely the utility, but the absolute necessity for some institution of the kind. As generally happens in such cases, this exertion was not lost, for, in 1794, it was decreed that an École Normale should be opened at Paris, "ou seront appelés de toutes les parties de la République, des citoyens déjà instruits dans les sciences utiles, pour apprendre, sous les professeurs les plus habiles dans tous les genres, l'art d'enseigner."

To follow these courses in the art of teaching, one potential schoolmaster was to he sent to Paris by every district containing 20,000 inhabitants. 1400 or 1500 young men, therefore, arrived in Paris, and in 1795 the courses of the school were opened first of all in the amphitheatre of the Museum of Natural History. The professors were chosen from among the most celebrated men of France, the sciences being represented by Lagrange, Laplace, Haüry, Monge, Daubenton, and Berthollet.

While there was this enormous progress abroad, represented especially by the teaching of science in Germany and the teaching of the teachers in France, things slumbered and slept in Britain. We had our coal and our iron, our material capital, and no one troubled about our mental capital-least of all the universities, which had become, according to Matthew Arnold (who was not likely to overstate matters), mere hauts lyckes, and "had lost the very idea of a real university," and since our political leaders generally came from the universities little more was to be expected from them.

Many who have attempted to deal with the history of education have failed to give sufficient prominence to the tremendous difference there must necessarily have been in scientific requirements before and after the introduction of steam power.

It is to the discredit of our country that we, who gave the perfected steam engine, the iron ship, and the locomotive to the world, should have been the last to feel the next wave of intellertual progress.

All we did at the beginning of the century was to found mechanics' institutions. They knew better in Prussia, " a bleeding and lacerated mass,".2 after Jena (1 806), King Frederic William III. and his councillors, disciples of Kant, founded the University of Berlin, "to supply the loss of territory by intellectual effort." Among the universal poverty money was found for the Universities of Kœnigsberg and Breslau, and Bonn was founded in 1818. As a result of this policy, carried on persistently and continuously by successive Ministers, aided by wise councillors, many of them the products of this policy, such a state of things was brought about that not many years ago $\mathrm{M}$. Ferdinand Lot, one of the most distinguished educationists of France, accorded to Germany "a supre macy in Science comparable to the supremacy of England at sea."

But this position has not been obtained merely by founding new universities. To Germany we owe the perfecting of the methods of teaching Science.

I have shown that it was in Germany that we find

1 "Schools and Universities on the Continent," p. $29 x$.

2 "University Education in England, France and Germany," Sir Rowland Blennerhassett, p. 25.

NO. I 51 I, VOL. 58] the first organised science teaching in schools. About the year 1825 that country made another tremendous stride. Liebig demonstrated that science teaching, to be of value, whether in the school or the university, must consist to a greater or less extent in practical work, and the more the better; that book work was next to useless.

Liebig, when appointed to Giessen, smarting still under the difficulties he had had in learning chemistry without proper appliances, induced the Darmstadt Government to build a chemical laboratory in which the students could receive a thorough practical training.

It will have been gathered from this reference to Liebig's system of teaching chemistry, that still another branch of applied science had been created, which has since had a stupendous effect upon industry; and while Liebig was working at Giessen, another important industry was being created in England. I refer to the electric telegraph and all its developments, foreshadowed by Galileo in his reference to the "sympathy of magnetic needles."

Not only then in chemistry, but in all branches of science which can be applied to the wauts of man, the teaching must be practical-that is, the student must experiment and observe for himself, and he must himself seek new truths.

It was at last recognised that a student could no more learn Science effectively by seeing some one else perform an experiment than he could learn to draw effectively by seeing some one else make a sketch. Hence in the German Universities the Doctor's degree is based upon a research.

Liebig's was the fons et origo of all our laboratoriesmechanical, metallurgical, chemical, physical, geological, astronomical, and biological. J. NORMAN LOCKYER.

\section{(To be continued.)}

\section{OPENING OF THE THOMPSON.YATES LABORATORIES AT UNIVERSITY COLLEGE, LIVERPOOL.}

THE latest addition to the noble series of buildings now fast surrounding the old lunatic asylum in which University College, Liverpool, started work seventeen years ago is devoted to the Schools of Physiology and Pathology. The professorships in these subjects were endowed and equipped by the late Mr. George Holt some years ago; and now suitable laboratories, on a magnificent scale, have been erected by the generosity of the Rev. S. A. Thompson-Yates at a cost of nearly $30,000 l$.

The building is of Liverpool grey brick and Ruabon terra-cotta in the renaissance Gothic style. It is L-shaped, one wing extending towards the north, where it joins the pathological museum of the old medical school buildings, and the other towards the east, the entrance being at the angle where the wings join. There are three floors and a basement. The two upper floors are occupied by physiology, under Prof. Sherrington; and the ground floor and basement by pathology, under Prof. Boyce. A large lecture theatre, the fine staircase and halls, and a few other apartments for the use of students are common to the two departments. Simplicity of plan has been the aim of the architects (Messrs. A. Waterhouse and Son), and there has been little or no expenditure of space in corridors and passages. As some of the rooms are to accommodate large numbers of workers, and so require to be lofty, while others are the private studies of individuals where a high ceiling would mean waste of space, a free use has been made of the expedient of mezzanines, by which the smaller rooms have been interpolated between the floors. 'The lecture theatre is very completely fitted for lantern illustration, including the projection microscope, the chromoscope, the 